\title{
Patrology
}

\section{Paradigms of Participation in Origen}

\author{
Dmitry Biriukov \\ National Research University Higher School of Economics, Saint Petersburg \\ State University of Aerospace Instrumentation \\ dbirjuk@gmail.com
}

\begin{abstract}
The article provides a classification of different kinds of participation in the conceptual framework by Origen, namely, those of natural participation and those of individual participation. In these concepts, Origen did not always borrow from Platonic philosophy - as it was commonly thought. In fact, Origen used as well Aristotelian and other approaches to the universalia and related questions.
\end{abstract}

\section{Keywords}

participation - divine substance - universals - logoi - theosis

In order to identify the logical foundations of Origen's doctrine, this article analyzes the way how Origen employed the concept of participation. This study was carried out as a part of my comprehensive research on the subject of participation and universals in Antiquity and Eastern Christianity, ${ }^{1}$ which

* The present study is a part of a larger project Nr 16-18-10202, "History of the Logical and Philosophical Ideas in Byzantine Philosophy and Theology”, implemented with a financial support of the Russian Science Foundation. 
distinguished three paradigms of participation in the philosophy of Antiquity: the Platonic (vertical) paradigm, the Aristotelian (horizontal) paradigm, and the Neoplatonic paradigm. The Platonic paradigm of participation implies that some being - the participating entity - possesses a certain property to a lesser extent than the participated entity, which embodies this property, while the participated property acts as a transcendent cause for the participating entity. ${ }^{2}$ The Aristotelian paradigm of participation points to the relation of an individual being to the species and genus, which constitute the nature carried by this individual, as well as the relation of species to the higher genus; this paradigm specifies that the individual being participates in its species and genus, and the species participate in the genus. ${ }^{3}$ The Neoplatonic paradigm of participation, which is a refinement of the Platonic paradigm, introduced to Ancient philosophy probably by Iamblichus includes the notion of a non-participating entity which indicates that the cause is transcendent to the caused and remains unaffected by the process of generating the caused in the context of the Platonic paradigm of participation.

In the Christian literature, the Platonic topic of participation appears in passing in the context of discussion of the ontological status and the fate of the soul after death in the Dialogue with Trypho the Jew by Justin the Philosopher who writes:

The soul assuredly is or has life. If, then, it is life, it would cause something else, and not itself, to live, even as motion would move something else than itself. Now, that the soul lives, no one would deny. But if it lives, it lives not as being life, but as participating in life; but that which participates in anything, is different from that in which it does participate

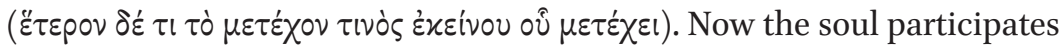
in life, since God wills it to live. ${ }^{4}$

Justin says that the human soul possesses life not because it is life as such, but because it participates in the life given to the human being by God. This life, in

1 D. Biriukov, "Hierarchies of Beings in the Patristic Thought. Gregory of Nyssa and Dionysius the Areopagite," in: Philosophy in Byzantium, ed. M. Knežević, Alhambra, CA, 2015, pp. 83-102; Idem, "Hierarchies of Beings in the Patristic Thought. Maximus the Confessor, John of Damascus and the Palamite literature," Scr 10 (2014), pp. 281-304; Idem, "On the Topic of Participation in the Divine Essence according to St Symeon the New Theologian in the Patristic Context," Scr 11 (2015), pp. 349-359.

2 Cf. Plato, Phaedo 10oc; 101c; 102b; Symposium 211b1-5; Republic 472c2, 476d1-2; Parmenides 158a.

3 Aristotle, Topics 121a10-15.

4 Justin, Tryph. 6.1.3-9, in Die ältesten Apologeten, ed. E.J. Goodspeed, Göttingen, 1915. 
accordance with the Platonic paradigm of participation, is understood as a transcendental universal cause of existence for the being that lives. Here Justin formulated virtually the same understanding of the concept of participation, which was mentioned by, for instance, Plotinus in Enneads VI, 4, 13, 6-8: the participating being is different from the participated being; otherwise the situation of participation would simply have not taken place.

Paradoxically, the development of the Platonic concept of participation in Christian literature was influenced by the Holy Scripture. Generally speaking, when the Scripture speaks of participation and commonality, it usually uses

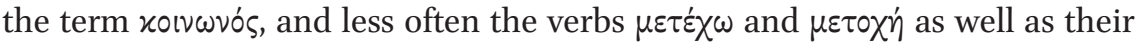
derivatives. The Epistles of the Apostles Paul and Peter discuss the participation of Christians in Christ - in his Passion and his glory. ${ }^{5}$ The Epistle to the

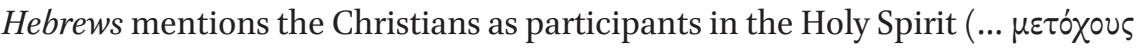

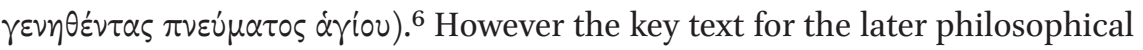
re-elaboration of the subject of participation is the following fragment from the Second Epistle of Peter:

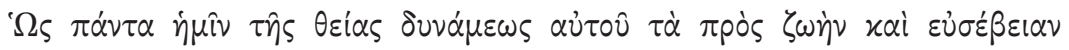

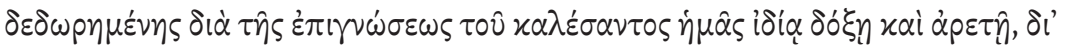

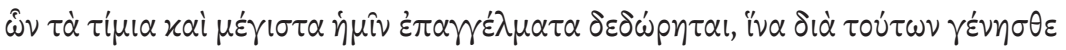

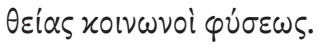

His divine power has given us everything we need for a godly life through our knowledge of him who called us by his own glory and goodness. Through these he has given us his very great and precious promises, so that through them you may participate in the divine nature, having escaped the corruption in the world caused by evil desires. ${ }^{7}$

See: 2 Cor. 1:7; Fil. 3:10; Heb. 4:14; 1 Pet. 4:13; 1 Pet. 5:1, and also the study: D. Powers, Salvation through Participation. An Examination of the Notion of the Believers' Corporate Unity with Christ in Early Christian Soteriology, Leuven-Paris-Sterling, 2001.

6 Heb. 6:4; cf. 2 Cor. 13:13.

72 Pet. 1:3-4. The historical and philosophical context of 2 Pet. 1:4 is discussed in: J. Starr, Sharers in Divine Nature: 2 Peter 1:4 in its Hellenistic Context, Stockholm, 2000; S. Finlan, "Second Peter's Notion of Divine Participation," in Theosis. Deification in Christian Theology, eds. S. Finlan, V. Kharlamov, Eugene, oR, 2006, pp. 32-50; see also: J. Kaufman, Becoming Divine, Becoming Human. Deification Themes in Irenaeus of Lyons, PhD thesis, Norwegian School of Theology, Oslo, 2009, pp. 215-224; D. Keating, The Appropriation of Divine Life in Cyril of Alexandria, Oxford, 2004, pp. 148-150. The too superficial and in many respects inaccurate article by $\mathrm{N}$. Russell is devoted to the exegesis of this fragment in the Byzantine literature: N. Russell, "Partakers of the Divine Nature" (2 Peter 1:4) in the 
In his book on 2 Pet. 1:3-4 and its historical context, James Starr showed that the expression "participation in the divine nature" in the Epistle of Peter meant the same as participation in the nature of Christ. ${ }^{8}$ The essence of this participation was the acquisition of or participation in the qualities of God, which were listed in 2 Pet. 1:1-3 and include the divine glory, virtue, and power. Norman Russell ${ }^{9}$ assumed the influence of the Platonic doctrine in this fragment of 2 Peter, but I doubt such an influence. Exploring the meaning of the passage from 2 Peter mentioned above, John Kaufman made an interesting suggestion that there is a parallel meaning between 2 Pet. 1:1-3 (the human being who acts according to his virtues participates in the divine perfection) and the philosophical concept of participation of the individual in the universal. ${ }^{10}$

It seems that Origen, ${ }^{11}$ who used this 2 Pet. 1:1-3 for his description of theosis, was the first Patristic author who incorporated the words from the Epistles about participation in the divine nature into a theological and philosophical context. Origen incorporates this theme into a consistent philosophy of participation. ${ }^{12}$ In general the Platonic paradigm of participation was constitutive for Origen's teaching, being one of the cornerstones of Origen's theological doctrine. However, as we shall see, the employment of the theme of participa-

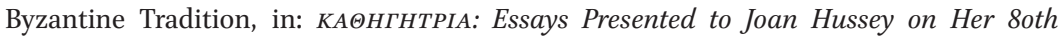
Birthday, Camberley, 1988, pp. 51-67; he demonstrates a more balanced view in his book: N. Russell, The Doctrine of Deification in the Greek Patristic Tradition, Oxford, 2004, pp. 151152, 181-184, 200-203 etc. J. Finch, in his dissertation entitled Sanctity as participation in the divine nature according to the ante-Nicene eastern fathers, considered in the light of Palamism, Ph. D. thesis, The Caspersen School of Graduate Studies at Drew University, 2002, leaves the history of 2 Peter 1:3-4 in the early Christian literature almost untouched. Starr, Sharers in Divine Nature, p. 45.

9 Russell, "Partakers of the Divine Nature," p. 53.

10 Kaufman, "Becoming Divine, Becoming Human," p. 220-221.

11 Cf. Russell, The Doctrine of Deification, p. 151; Kaufman, Becoming Divine, Becoming Human, p. 215 .

12 Concerning the concept of participation in the doctrine of Origen see esp.: D. Balás, "The Idea of Participation in the Structure of Origen's Thought. Christian Transposition of a Theme of the Platonic tradition", in Origeniana. Premier colloque international des études origéniennes (Montserrat, 18-21 Septembre 1973) (Quaderni di Vetera Christianorum, 12), Bari, 1975, pp. 257-275 (I was mostly influenced by this article in my interpretation of the doctrine of Origen presented below). See also: A. Bueno, “«Plenitud»y «Participación». Nociones estructurantes de la doctrina teológica de Orígenes de Alejandría," Augustinianum, 50 (2010), pp. 27-6o; Russell, The Doctrine of Deification, pp. 147-152; J. Rius-Camps, "Comunicabilidad de la naturaleza de Dios segun Origenes", $O C P, 34$ (1968), pp. 5-37; 36 (1970), pp. 201-247; 38 (1972), pp. 430-453; Idem, El dinamismo trinitario en la divinizacion de los seres racionales según Origenes (OCA, 188), Rome, 1970. 
tion by Origen allowed for deviations from the Platonic paradigm and included Aristotelian and "neutral" trends. The Platonic paradigm of participation was reworked in Origen in the context of two major discourses inside which several subdivisions can be identified.

First, this is manifested in Origen's concept of participation by nature when he discussed participation of beings of the created world in God according to their natural qualities, or the participation of the material beings in the principles and logoi contained in the intellectual world according to their natural qualities (we have already seen such treatment of natural participation in Christian literature before Origen in Justin the Philosopher). Generally speaking, this trend only tentatively appeared in Origen and was more fully elaborated in the later Patristic authors. It entailed that beings of the same nature participated in the transcendental participated principles which acted as universals-before-things endowing the beings with their natural capacities, in one and the same way. This way of participation is different for the beings of different natures and depends upon the place of the natural perfections owned by the beings of each particular nature within the order and hierarchy of these perfections.

Second, Origen used the discourse of individual participation both in his discussion of the relationship between the Persons of the Holy Trinity and of the union of Man with God. In the Trinitarian context, Origen said that the Son was God according to the participation ( $\mu \varepsilon \tau \circ \chi \hat{n})$ in the divinity of the Father. ${ }^{13}$ Just as the relation of the Son to the Father, Origen described the relation of the Spirit to the Son also using the language of participation. The Spirit needs the cooperation of the Son in respect to being, wisdom, understanding, justice, and in general all the perfections; He possesses all these according to participation ( $\varkappa \alpha \tau \dot{\alpha} \mu \varepsilon \tau 0 \chi \dot{\eta} \nu)$, understood here in the Platonic sense, in that which belongs to Christ. ${ }^{14}$ According to Origen, although the Son assumed divinity and the divine attributes from the Father, they belonged to Him in a substantial and not in an accidental way. This is confirmed by Origen's application of divine names with the prefix $\alpha$ i $\tau 0$ - to the Son, ${ }^{15}$ as well as Origen's statement that it was wrong to say that the Son participated in the righteousness, but rather that HeHimself was that righteousnessin which righteous people participated, ${ }^{16}$

13 Origen, In Joan. II, 17, 4-6, in: Origène, Commentaire sur saint Jean, Ed. C. Blanc (sC 120), Paris, 1966, pp. 216-218.

14 Origen, In Joan. II, 76, in: Origène, Commentaire sur saint Jean, p. 256.

15 Cf. Balás, "The idea of participation," p. 263.

16 Origen, Contra Celsus vi, 64. Cf.: De Princ. II, 6, 6, in: Origène, Traité des principles, Tome I (Livres I et II), Introduction, texte critique de la Philocalie et de la version de Rufin, traduc- 
or by Origen's words that human beings would become God according to participation ( $\varkappa \alpha \tau \dot{\alpha} \mu \varepsilon \tau 0 v \sigma i \alpha \nu)$, while Christ was God according to substance ( $\varkappa \alpha \tau^{\prime}$ ovं $\left.\sigma^{\prime} \alpha v\right) .{ }^{17}$ This opposition of "according to substance-according to participation," which was formulated in the latter case, would be adopted by the later Patristic authors. ${ }^{18}$ Keeping all this in mind, we may agree with David Balás that the discourse of participation used by Origen in the Trinitarian context did not imply a measure of participation, which would depend on the will of the participating beings, that is, the Son and the Holy Spirit, but the participation of the Son in the Father and the Spirit in the Son being constant and unchangeable. ${ }^{19}$

In the case when the concept of participation was used for describing the individual, dynamic unity of human beings with God, Origen implied that participation depended on the disposition of the will of the participating beings. ${ }^{20}$ In this context, Origen and the subsequent Christian authors used 2 Pet. 1: 3-4 in their discussion of individual participation. The allusion to this fragment could be skillfully incorporated into the general Platonic discourse of participation, which we can see in Origen's De principiis IV, 4, 9, where both the "individual" and the "natural" discourses are employed.

This fragment has survived in the Latin translation, but the original terminology of participation is quite evident:

tion par H. Crouzel et M. Simonetti, (SC 252), Paris, 1978, p. 320-321.

17 Origen, In Ps. in catenae, Ps. 135: PG 12, col. 1656A.

18 See, for example, Athanasius of Alexandria, Contra gentes 46, PG 25, col. 93BC; Fourth Epistle to Serapion 2.4, PG 26, col. 613C; Basil of Caesarea, Contra Eunomium 3, PG 29, col. 660.14-30; Gregory of Nyssa, Contra Eunomium I.1.276.1-277.1, in:W. Jaeger, Gregorii Nysseni opera, vol. 1, Contra Eunomium Libri I et II, Leiden, 1960, p. 107; Symeon the New Theologian, Hymn 50.198-202, in: Symeon der Neue Theologe, Hymnen, ed. A. von Kambyles, Berlin, 1976, p. 402. See also D. Balás, METorsIA @EOr. Man's Participation in God's Perfections according to St. Gregory of Nyssa, Rome, 1966, pp. 11-12, 6o-62. Balás, "The idea of participation," p. 271.

20 In opposition to the "natural" participation David Balás calls this participation "supernatural”, see: Balás, “The idea of participation,” pp. 266-270. N. Russell follows Balás in this respect (Russell, The Doctrine of Deification, p. 147; he calls this kind of participation dynamical). In general, my distinction between the natural and the individual discourses of participation in Origen is close to the distinction made by David Balás, who spoke of natural and supernatural levels of participation in Origen. The difference in my understanding of this distinction, is that I distinguish the individual level instead of the supernatural. This difference seems more adequate because it is more universal. The discourse of individual participation encompasses the participation in the context of relations between the Persons of the Holy Trinity as well as participation of deified people in God, described as supernatural by Balás. 
Every one who participates in anything, is unquestionably of one essence and nature with him who participates in the same thing. For example, as all eyes participate in the light, so accordingly all eyes which participate in the light are of one nature; but although every eye participates in the light, yet, inasmuch as one sees more clearly, and another more obscurely, every eye does not equally share in the light. And again, all hearing receives voice or sound, and therefore all hearing is of one nature; but each one hears more rapidly or more slowly, according as the quality of his hearing is clear and sound. Let us pass now from these sensuous illustrations to the consideration of intellectual things. Every mind which participates in intellectual light ought undoubtedly to be of one nature with every mind which participates in a similar manner in intellectual light. If the heavenly virtues, then, participate in intellectual light, i.e., in divine nature, because they participate in wisdom and holiness, and if human souls, have participated in the same light and wisdom, and thus are mutually of one nature and of one essence - then, since the heavenly virtues are incorruptible and immortal, the essence of the human soul will also be immortal and incorruptible. And not only so, but because the nature of Father, and Son, and Holy Spirit, in whose intellectual light alone all created things participate, is incorruptible and eternal, it is altogether consistent and necessary that every substance which participates in that eternal nature should last for ever, and be incorruptible and eternal, so that the eternity of divine goodness may be understood also in this respect, that they who obtain its benefits are also eternal. ${ }^{21}$

First, Origen used the examples of participation of the eye in light and the hearing in sound for arguing that the same way of participation typical of different beings meant that those beings were of the same nature. Individuals of the same nature might carry out their typical way of participation either naturally, that is, in a good way, or unnaturally, that is, in a bad way. The discourse of participation used in these examples, was neither Platonic, nor Aristotelian - it was neutral.

21 Origen, IV, 4,9 (36): 337-368, in: Origène, Traité des principles, Tome III (Livres III et IV), Introduction, texte critique de la Philocalie et de la version de Rufin, traduction par H. Crouzel et M. Simonetti, (sC 268), Paris, 1980, pp. 422-424. All translations of Origen were based on or taken from: Ante-Nicene Fathers, vol. 4, transl. by F. Crombie, edited by A. Roberts, J. Donaldson, and A. Cleveland Coxe, Buffalo, NY, 1885, and Ante-Nicene Fathers, Vol. 9, Recently Discovered Additions to Early Christian Literature; Commentaries of Origen, ed. A. Menzies, New York, 1912. 
Then Origen turned to his own doctrine saying that human minds and heavenly powers participate (in the "vertical" Platonic sense) in the intellectual light thus also participating in the divine nature. The allusion to 2 Pet. 1:3-4 is evident here. ${ }^{22}$ Thus, it follows that according to Origen, the human minds and the heavenly powers were of the same nature and substance, ${ }^{-2324}$ and the human soul is incorruptible and eternal as being able to participate in the divine nature which Origen understood as the nature of the Father, the Son, and the Holy Spirit, that is, the nature of the Holy Trinity. When Origen spoke about "divine nature," or the nature of the Father, the Son, and the Holy Spirit, it is clear that his understanding of nature included the context of causality - for Origen, participation in the divine nature meant that this nature was the cause for acquiring the qualities typical of divinity by nature, by the beings participating in it. This brings the concept of participation in the divine nature in the way it was used by Origen closer to the original understanding of 2 Pet. 1:4.

Now I will turn to Origen's teaching of the natural participation in more detail. In this respect the following fragments of De principiis should be cited:

God the Father bestows upon all, existence; and participation in Christ, in respect of His being the word of reason, renders them rational beings. From which it follows that they are deserving either of praise or blame, because capable of virtue and vice. On this account, therefore, is the grace of the Holy Ghost present, that those beings which are not holy in their essence may be rendered holy by participating in it. Seeing, then, that firstly, they derive their existence from God the Father; secondly,

22 Norman Russell (Russell, The Doctrine of Deification, p. 151, n. 62) listed the fragments where Origen quoted 2 Pet. 1:4 in his discussion of participation in the divine nature: $D e$ princ. IV, 4, 4 and in In Rom. 4, 9, PG 14, col. 997C; Contra Celsus 3, 37; In Lev. 4, 4, in: Origenes Werke III, Homiliae in Ieremiam, Fragmenta in Lamentationes, (Die Griechischen Christlichen Schriftsteller der Ersten Drei Jahrhunderte 6), Leipzig, 1901, p. 319.16-17. The fragment of De Princ. IV, 4, 9 quoted above was omitted from this list, but it is evident that when Origen spoke about participation in the divine nature, he was alluding to 2 Pet. 1:4. In his book, N. Russell (p. 148) mentioned this passage and its discussion of the participation in the divine nature, but did not connect it to the interpretation of 2 Pet. 1:4.

In respect to such discourse of participation, Norman Russell spoke about the "horizontal" dimension of participation in the doctrine of Origen (Russell, The Doctrine of Deification, p. 148).

Here I will not go into the details of the "Origenist myth" about the fallen minds. 
their rational nature from the Word; thirdly, their holiness from the Holy Spirit. ${ }^{25}$

That the working of the Father and the Son operates both in saints and in sinners, is manifest from this, that all who are rational beings are partakers of the Word, i.e., of Reason, and by this means bear certain seeds, implanted within them, of Wisdom and Justice, which is Christ. Now, in Him who truly exists, and who said by Moses, "I Am Who I Am" (Ex. 3:14), all things, whatever they are, participate; which participation in God the Father is shared both by just men and sinners, by rational and irrational beings, and by all things universally which exist. The Apostle Paul also shows truly that all have a share in Christ, when he says, "Say not in your heart, 'Who shall ascend into heaven? (that is, to bring Christ down from above); or who shall descend into the deep?' (that is, to bring up Christ again from the dead. But what says the Scripture? The word is near you, even in your mouth, and in your heart" (Rom. 10:6-8). By which he means that Christ is in the heart of all, in respect of His being the word or reason, by participating in which they are rational beings. ${ }^{26}$

According to Origen, created beings participated in God with their substantial qualities because of their very existence (the Platonic connotations of participation are evident here). Moreover, there is a certain order of participation of beings in God: according to their existence, all created beings participate in God the Father - the source of all existence, while in addition to participating in God the Father according to their existence, rational beings also participate in the Sun as the Logos - the source of all reason. This theological and philosophical discourse implied that the hypostases of the Holy Trinity act as universal participated causes or principles ${ }^{27}$ for the multitude of beings. This participation of beings in God the Father and of rational beings in the SonLogos does not depend on the state of the participating individuals: both people worthy of praise and worthy of punishment participate in the Son according to their rational capacity. Therefore this doctrine implied (although not expressed explicitly) that natural participation of all beings in God the Father according to their existence and participation of rational beings in the Logos

\footnotetext{
25 Origen, De princ. I, 3, 8: 272-283, in Origène, Traité des principles, Tome I (Livres I et II), p. 162.

26 Origen, De Princ. I, 3, 6: 155-171, in Origène, Traité des principles. Tome I, p. 154.

27 They are universal precisely as causes, viewed in relation to the plurality of the caused, for which this causality is common.
} 
according to their rational capacity could be "more" or "less." However, the theological language used by Origen in this fragment also contains the instrument for describing participation in God in dynamic terms, typical of the saints, which presupposed that participation in God could be "more" or "less" for the participating individual. ${ }^{28}$ Such participation of the saints in God was described by Origen as participation in the third Person of the Holy Trinity, the Holy Spirit.

If we compare the discourses of participation from the fragments of De principiis I, 3, 6 and I, 3, 8 on the one hand, and from the fragment of De principiis IV, 4, 9, on the other hand, we may see that the static state of natural participation of created beings in God was implied in the former case (participation according to existence and rational capacity), while a somewhat different discourse of natural participation is followed in the latter case, which entails some deviation from the understanding of natural participation in the static sense. According to that discourse, although individuals of the same nature participated in the participated entity in the same way, in reality such natural participation in the divine nature which acts as a universal principle, was possible in different measure; the measure of participation depended on whether the natural mode of participation was implemented by each particular individual naturally or not.

This distinction in the discourses of participation can be explained by the fact that in De principiis IV, 4.9, Origen was discussing individual participation in God in terms of natural participation. Origen must have had in mind that it was inherent in all human beings to participate in God according to nature in the sense of personal unification with God in theosis (which is called in this article "the individual participation in God"). However, this natural capacity might or might not be implemented in a natural way. If natural implementation of this capacity does not occur, the human being would still have existence and intellect, but remain outside of personal unification with God.

Thus, we may say that in the context of the discourse of participation, appearing in the fragments of De principiis I, 3, 6 and I, 3, 8, it is assumed that natural participation in God was inherent in the same measure in all beings according to their existence, and in rational beings according to their intellectual capacity, while individual participation in God in theosis could be implemented by rational beings to varying degrees. The discourse of participation followed in De principiis IV, 4, 9 implies that the concept of the same measure of participation applies to the natural capacity typical of every being of human 
nature to individually participate in God in theosis, and not to the natural participation in God.

These examples show that Origen used different language for describing individual participation of rational beings in God in theosis. In De principiis I, 3, 6 and I, 3, 8, where Origen discussed the order of the participation modalities, individual participation was described in accordance with the logic of this order in the language of participation in the Holy Spirit, while in De principiis IV, 4, 9 Origen did not elaborate on the order of participation, but used the language of participation in the divine substance alluding to 2 Pet. 1:3-4.

Speaking about Origen's doctrine of participation, we should touch upon the topic of participation of all beings in the Son, the Logos, or Wisdom. Like Clement of Alexandria, Origen described God the Father in terms of unity and simplicity, while the Son was characterized by plurality, ${ }^{29}$ since He was the Principle of plurality of created beings. ${ }^{30}$

Following Philo ${ }^{31}$ and Clement of Alexandria, ${ }^{32}$ Origen developed the doctrine of the Logos-Wisdom who contains in Himself the intelligible principles and logoi of all creation, in which the beings of the created world participate. ${ }^{33}$ God created the beings of the created world by the Logos-Wisdom according to

29 Here is the line which can be traced to Plato's Parmenides, possibly through Clement. Concerning the teaching of Clement in this respect see especially: A. Choufrine, Gnosis, Theophany, Theosis, (Patristic Studies 5), New York, 2002, pp. 167-179.

30 See: "Now God is altogether one and simple ( reasons, since God set Him forth a propitiation (Rom. 3:25) and the first fruits of the whole creation, is made many things, or perhaps all these things; the whole creation, so far as capable of redemption, stands in need of Him (cf. Rom. 8:21)" (In Joan. I, 119, in: Origène, Commentaire sur saint Jean, p. 122).

Cf. Philo, De opif. 16; 36; 129; Her. 280; De Plant. 50; De ebriel. 133; De confus. Ling. 172. In general for the teaching of Philo on logoi in the historical-philosophical context see: R. Radice, "Logos tra stoicismo e platonismo. II problema di Filone," in: Dal logos dei greci e dei romani al Logos di Dio Ricordando Marta Sordi, eds. R. Radice, A. Valvo, (Temi metafisici e problemi del pensiero antico. Studi e testi 122), Milano, 2011, pp. 131-145.

See: Clement of Alexandria, Strom. 5, XIV, 93-94, in Clemens Alexandrinus zweiter Band: Stromata Buch I-VI, ed. O. Stählin, Leipzig, 1906, pp. 387-388; 4, XXV, 155-157, in Clemens Alexandrinus zweiter Band, p. 317-318.

33 On this subject in Origen in relation to the previous tradition see esp.: I. Ramelli, "CristoLogos in Origene. Ascendenze medioplatoniche e filoniane, passaggi in Clemente e Bardesane, e anti-subordinazionismo," in Dal logos dei greci, eds. R. Radice, A. Valvo, pp. 295-318. Cf.: Bueno, “«Plenitud» y «Participación»”, pp. 54-55. 
these logoi ${ }^{34}$ The creation always had its prefiguration in the Divine Wisdom. ${ }^{35}$ According to Origen, there were logoi for species and genera of beings ${ }^{36}$ (we may say that such logoi correlate with universals-before-things) as well as for individual beings. ${ }^{37}$ The logoi of beings correlate with the Logos-Word as parts with the whole and species with the genus. ${ }^{38}$

Thus, the Logos-Wisdom is participated in, first, by all created beings, ${ }^{39}$ second, by beings possessing rational capacity (even if they do not live in accordance with reason) ${ }^{40}$ and third, by truly rational, righteous and holy people. ${ }^{41}$ In the first case Origen's argument implied that the Logos-Wisdom in some way contained universals-before-things, and in the second case - that the Logos was a universal participated principle for rational beings.

Speaking about human beings as beings possessing rational capacity, Origen identified two meanings of logos entailing two meanings of participation: in one sense all people participated in logos (with the small letter l) since they all have a natural capacity to think due to their participation in the Logos-Wisdom; in the other sense people who have reached spiritual perfection, participate in the Logos (with the big letter L):

De Princ. I, 3, 6, in Origène, Traité des principles. Tome I, p. 154; I, 4, 4-5, Ibid, p. 170-172; In Joan. XIX, 22, 147, in Origenes, Vierter Band, Der Johanneskommentar, (Die Griechischen Christlichen Schriftsteller der Ersten Drei Jahrhunderte 10), Leipzig, 1903, p. 324; I, 19, 109115, in: Origène, Commentaire sur saint Jean, p. 118-122; I, 34, 243-246, in: Origène, Commentaire sur saint Jean, p. 180-182; Contra Celsus v, 39, in Origene, Contre Celse, Livres v et VI, ed. M. Borret, (SC 147), Paris, 1969, pp. 116-120. Cf. also the words of Origen that all living beings are such because they participate in Life as it is (In Joan. Fr. 2, in Origenes, Vierter Band, Der Johanneskommentar, p. 485.24-26). Here Origen practically repeats the similar statement by Justin the Philosopher (Tryph. 6, 1, 3-9, see above). De Princ. I, 4, 4-5, in Origène, Traité des principles. Tome I, p. 170-172.

36 In Joan. I, 19, 114, cf. De Princ. I, 2, 2, in Origène, Traité des principles. Tome I, p. 112-114; I, 4, 5. Ibid, p. 172; I, 7, 1 Ibid, p. 206-208; III, 6, 4, in Origène, Traité des principles, Tome III, p. 242-244.

De Princ. I, 2, 2, in Origène, Traité des principles. Tome I, p. 112-114.

38 Contra Celsus v, 22, in Origène, Contre Celse, p. 68, cf. In Joan. I, 34, 244, in: Origène, Commentaire sur saint Jean, p. 180.

In Joan. I, 34, 244, in: Origène, Commentaire sur saint Jean, p. 180; XIX, 22, 147, in Origenes, Vierter Band, Der Johanneskommentar, p. 324.

40 In Joan. I, 37, 269-270, in: Origène, Commentaire sur saint Jean, p. 194, cf. I, 34, 246, Ibid., p. 182.

41 Contra Celsus VI, 64 in Origène, Contre Celse, p. 338-340; In Joan. I, 37, 268, in: Origène, Commentaire sur saint Jean, p. 194. 
But the logos in man, in which we have said that our whole race participated in, is spoken of in two senses; first, in that of the filling up of ideas which takes place, moron excepted, in every one who passes beyond the age of boyhood, but secondly, in that of the consummation, which takes place only in the perfect. ${ }^{42}$

Although it was mentioned only in passing, here we may see the Aristotelian paradigm of participation, rare for Origen: all people participate in the capacity of reasoning, constitutive for the human nature. Since this capacity is clearly understood in this fragment not as transcendental for human individuals, but as something inherent in each participating human, we can affirm that exactly the Aristotelian paradigm is used here, since reason is understood in the sense of a universal-in-things (in this case, in the human individuals).

In sum, two main discourses of participation can be discerned in Origen: natural participation and individual participation.

Natural participation in Origen can be subdivided into four types, including

$N^{1}$ : the order of natural participation of species of created beings in the Persons of the Holy Trinity; according to this order, all beings participate in God the Father according to existence, while rational beings participate in the Son according to their rational capacity; God the Father and God the Son act as universal participated causes for the multitude of beings.

$N^{2}$ : all created beings naturally participate in the logoi contained in the Logos-Wisdom, although the mode of rational beings' participation in the Logos differ from the mode in which other beings participate in the Logos; this discourse assumes that the Logos-Wisdom in some way contains universals-before-things.

$N 3$ : all rational beings have a natural capacity to unite with God; this discourse entails that the divine nature, common for the Father, the Son, and the Holy Spirit, acts as a universal participated principle in respect to the natural capacity of rational beings to unite with God.

$N^{4}$ : all people naturally participate in the capacity of reasoning, constitutive for the human nature. The Aristotelian paradigm is used here, which assumes the presence of a universal-in-things (logos) in rational beings.

The individual participation in Origen can be subdivided into two types;

$I^{1}$, associated with relations between the Persons of the Holy Trinity: the Son participates in the divinity of the Father, and the Holy Spirit participates in the qualities of the Son. 
$I^{2}$, associated with the subject of unification of righteous people to God. This type may be subdivided into two:

$I^{2 \text { a: }}$ individual unification of the rational being with God is described using the language of participation in the Holy Spirit. In respect to natural participation this correlates with $N^{1}$.

$I^{2 \mathrm{~b}}$ : individual unification of the rational being with God is described using the language of participation in the divine substance with an allusion to 2 Pet. 1:3-4. In respect to natural participation this correlates with $N$.

These observations may help us to clarify the concept of David Balás concerning the doctrine of participation in Origen. According to Balás, in general terms Origen's concept of participation presumes that the lower level of being has a certain perfection being dependant as regards this perfection on the higher level of being which fully possesses this perfection and is its source. ${ }^{43} \mathrm{It}$ seems that such an understanding is commonplace in the study of Origen ${ }^{44}$ Such an understanding of participation corresponds to the Platonic paradigm of participation mentioned above. However, as we have seen, although the Platonic paradigm is dominant in Origen, there are also manifestations of a paradigm of participation, which can be called Aristotelian, as well as an understanding of participation in neither Platonic nor Aristotelian sense.

A new trend in the development of the theme of participation in Christian theology emerged during the Arian controversy and was associated with the use of the concept of the "non-participated" by the representatives of the Arian party. This trend will be discussed in a special study.

43 Balás, “The idea of participation," p. 270.

44 See for example: Russell, The Doctrine of Deification, pp. 147-148. This does not contradict the horizontal dimension of participation, emphasized by N. Russell (p. 148, see note 20 above), since it points not to the relation between the participating and the participated, but to the relation between the participants themselves: it is connected to the idea, that the same way of participation of different beings in the participated indicates that they have the same nature. 